\title{
SUMMER CAMPS FROM THE PERSPECTIVE OF PARTICIPANTS AND ORGANISERS
}

\author{
ANETA ANNA OMELAN ${ }^{1}$, BARBARA BREŚl, MAREK RACZKOWSKI르, ROBERT PODSTAWSKI ${ }^{1}$, \\ TIBOR POLGÁR ${ }^{3}$, MIKLÓS KOLTAI ${ }^{3}$ \\ ${ }^{1}$ University of Warmia and Mazury in Olsztyn, Faculty of Environmental Sciences, Department of Tourism, \\ Recreation and Ecology, Olsztyn, Poland \\ ${ }^{2}$ University of Warmia and Mazury in Olsztyn, Faculty of Technical Sciences, Department of Mechatronics, \\ and Technical and Information Technology Education, Olsztyn, Poland \\ ${ }^{3}$ Eötvös Loránd University, Faculty of Education and Psychology, Institute of Sport Sciences, Szombathely, \\ Hungary
}

Mailing address: Aneta Anna Omelan, University of Warmia and Mazury in Olsztyn, Faculty of Environmental Sciences, Department of Tourism, Recreation and Ecology, 5 Oczapowskiego Street, 10-719 Olsztyn, tel.: +48 89 5233456, fax: +48 89 5233969, e-mail: aneta.omelan@uwm.edu.pl

\begin{abstract}
Introduction. Summer camps are the most important form of organised leisure activity for children and adolescents, and their popularity has been increasing year after year. Providing tourism services for this group of recipients constitutes a big challenge for the organisers because they have to satisfy the expectations of not only the participants but also their parents. Hence, the aim of the study was to obtain data making it possible to estimate the degree of convergence between the needs of summer camp participants, their parents' needs, and the tourism product, that is summer camp. Materials and methods. The study involved one hundred participants of a summer camp, aged 11-17 years. A diagnostic survey carried using direct interviews and questionnaires. The data have been processed and analysed statistically by means of Excel and Statistica v.12; a significance test was used for comparing two proportions at the significance level $\alpha=0.05$ (with $\mathrm{p}<\alpha$ indicating the presence of statistically significant differences and $\mathrm{p} \geq \alpha$ indicating a lack of statistically significant differences). Results. The children of educated mothers participated in summer camps significantly more often than children of mothers with vocational education $(\mathrm{p}=0.0115)$ and secondary education $(\mathrm{p}=0.0422)$. When selecting the summer camp, most respondents $(44.57 \%)$ paid attention to the degree of correspondence between the programme and their interests. The camps that were the most popular were sport summer camps $(41.30 \%)$. Boys chose survival summer camps more often than girls $(\mathrm{p}=0.0360)$ whereas girls preferred active and sailing summer camps $(\mathrm{p}=0.006)$. The most attention in a summer camp was paid to the staff. Conclusions. When choosing a summer camp, children and parents pay special attention to whether or not the programme is rich in attractions; however, it is the staff that conditions positive emotions of the participants as well as their good memories. Organisers know how important the staff are and that they are the warrant of the summer camp's success. The results presented confirm that preparing a summer camp offering requires much work and involvement because one must satisfy the expectations of both participants and parents, who use different criteria of camp evaluation.
\end{abstract}

Key words: summer camp, children, adolescents, parents, tourism

\section{Introduction}

Summer camps for children and adolescents have a long tradition. During the Industrial Revolution, summer camps offered recreation and respite from urban life, and educational and consulting methods were incorporated into the summer camp formula over time to promote the participants' harmonious development [1]. Today, school students are increasingly overburdened by the fast pace of modern life, and the main aim of summer camps is to provide them with an optimal environment for safe and healthy recreation as well as physical and mental recovery [2]. Summer camps are meant to be a pleasant experience which encourages children to achieve goals, creates a sense of community and friendship, improves well-being, and contributes to the participants' overall development [3]. Summer camps promote culture, trekking, tourism, and community involvement, by instilling pro-social attitudes in the participants [4]. They provide opportunities for education and socialisation and foster a favourable environment for young people's development [5].

Juvenile clients of travel agencies are a unique group of customers because they are represented by their parents. The choice of summer camp can be made by both the parents and the child, but it is the parents who effect the purchase [6]. The number of summer camp organisers is on the rise, and this form of recreation weighs heavily on the budgets of Polish families. Parents give priority to their children's recreational needs over their own holiday plans [7]. The Polish population of 8- to 18-year-olds 
began to increase in 2016. The number of prospective summer camp goers is increasing by around 30,000-50,000 children per year, and it is expected to reach approximately 4 million by 2024 [8]. According to a survey of the Public Opinion Research Centre (CBOS) [9], the social benefit programme for families implemented by the Polish government ("500+") has contributed to the growth of the adolescents' travel market. Summer camps are becoming increasingly popular. In 2016, the percentage of children who stayed at a summer camp for at least one week was the highest since 1993, and 56\% of the families surveyed sent all their children to at least a one-week camp [9]. Camp operators have to cater to the clients' growing expectations. For the children, the main attraction is breaking free from parental care, whereas the parents want the programme to be filled with activities that provide their children with the greatest benefits [10]. Summer camp organisers have to meet these needs and cater to the growing expectations of young clients and their parents.

This article presents the results of a study that evaluated the extent to which organised summer camps cater to the needs and expectations of children and their parents.

\section{Material and methods}

The study was carried out among the participants of a summer camp (a "green school") in the Rewita Waplewo Recreational Centre in May and June 2017. The summer camp was studied as an organised type of summer recreation for children and adolescents.

The survey involved a questionnaire and direct interviews. Data were collected with the use of:

- a survey questionnaire composed of general demographic questions and 11 questions relating directly to the participants' stay in the camp,

- an interview questionnaire composed of ten questions for two tour operators in Olsztyn with extensive experience in organising tourist events for children and adolescents (summer and winter camps as well as school trips).

The results were processed and analysed statistically using Excel and Statistica v. 12 software, and the significance of differences between two proportions was tested at $\alpha=0.05$. The probability values calculated denoted the following:

- absence of statistically significant differences at a probability level of $\mathrm{p} \geq \alpha$,

- presence of statistically significant differences at a probability level of $\mathrm{p}<\alpha$.

The study was performed on 100 camp participants, of which $53 \%$ were female. The largest group of respondents (63\%) were aged 11-14 years, and the remaining participants were aged 15-17 years. In the population surveyed, $22 \%$ were only children, $33 \%$ had one sibling, 33\% had two siblings, and 12\% had three or more siblings. The smallest group of respondents $(8 \%)$ resided in towns with a population of $10,000-20,000$, and the largest group (42\%) resided in cities with a population of $21,000-99,000$. Rural dwellers accounted for $10 \%$ of the population studied, and $22 \%$ of respondents lived in large cities with populations between 50,000 and 99,000 inhabitants. The remaining respondents $(18 \%)$ resided in cities with a population of 100,000-200,000. The respondents' mothers were better educated than their fathers: $62 \%$ of the mothers had university education (this figure was only $27 \%$ among fathers), $24 \%$ of the mothers and $44 \%$ of the fathers had secondary school education, $10 \%$ of the mothers and $24 \%$ of the fathers had vocational education, and $4 \%$ of the mothers and $5 \%$ of the fathers had primary school education.
Two other persons who were interviewed were representatives of the largest tour operators in the region of Warmia and Masuria, which also had a good reputation across Poland), specialising in the tourism for children and youth. Szarpie Travel is a company originating from the scout tradition that has been organising summer camps for fifteen years. About 10,000 young people use its services every year. The interview was given by the head of the Masuria Department, who has been performing this function for five years. The second interview was given by the owner of the travel agency Europa-Bus, which, in close cooperation with the travel agency Mill Tour, has been successfully involved in organising children's and youth tourism for eighteen years.

\section{Results}

The highest number of respondents attended camps in summer, and the participants whose mothers had university education were most widely represented in this group. Significant differences were noted between summer camp participation and the mothers' education: the children of mothers with a university degree were more likely to participate in organised summer recreation than the respondents whose mothers had vocational $(\mathrm{p}=0.0115)$ and secondary school $(\mathrm{p}=0.0153)$ education. In the population surveyed, $83 \%$ of the students attended school field trips, and these were mostly residents of cities with a population of $21,000-99,000$. A significant difference $(\mathrm{p}=$ 0.0422 ) in school trip participation was observed between this group of respondents and residents of small towns. Field trip attendance was also significantly correlated with the mother's education: respondents whose mothers had a university degree were significantly more likely to participate in school trips than subjects whose mothers had vocational $(p=0.0096)$ and secondary school $(p=0.0072)$ education. More than half of the respondents went on summer holidays with their families, and $10 \%$ of the subjects participated in family weekend outings. In the group surveyed, $11 \%$ participated in winter camps, and 2\% went to green schools only (the percentages of responses do not add up to 100 because the participants could select more than one response). Most respondents had summer camp experience. More than $50 \%$ of the population surveyed went to camp every summer, and the children of mothers with a university degree were most numerous in this group. A significant difference in summer camp attendance was observed between the respondents whose mothers had vocational education and respondents whose mothers had university education $(p=0.0265)$. The remaining students went to summer camps every other year or less frequently. Most children participated in summer camps to make new friends and spend the summer away from their parents. Around $20 \%$ of the subjects claimed that they were forced to go to camp by their parents. More than half of the respondents selected the camp together with their parents, whereas $25 \%$ of the students made that choice independently. In the remaining cases, the decision was made by the parents. Most participants opted for camps with programmes that matched their interests, whereas the remaining respondents chose camps offering numerous and/or new activities. The respondents were least likely to pay attention to the price, the camp location, and the standard of camp facilities. The subjects surveyed were most eager to participate in sports camps, followed by the "other camp types" category, mostly sailing camps and camps involving numerous physical activities. Art, language, and survival camps were less popular. The popularity of various camp types differed significantly between the sexes. Boys were significantly more likely to 
Table 1. Summer camp participation

\begin{tabular}{|c|c|c|}
\hline $\begin{array}{l}\text { Recreational options in population } \\
\text { surveyed }(N=100)\end{array}$ & $\begin{array}{l}\text { Responses } \\
\text { number }\end{array}$ & $\begin{array}{l}\text { Response } \\
\text { percentage }\end{array}$ \\
\hline Only green schools* & 2 & 2.00 \\
\hline School trips & 83 & 83.00 \\
\hline Winter camps & 11 & 11.00 \\
\hline Family holidays & 51 & 51.00 \\
\hline Family weekend outings & 11 & 11.00 \\
\hline Summer camps & 91 & 91.00 \\
\hline \multicolumn{3}{|c|}{ Participation in summer camps $(\mathrm{N}=100)$} \\
\hline Yes & 92 & 92.00 \\
\hline No & 8 & 8.00 \\
\hline \multicolumn{3}{|c|}{ Frequency of participation in summer camps $(\mathrm{N}=92)^{4}$} \\
\hline Every summer & 48 & 52.17 \\
\hline Every other summer & 25 & 27.17 \\
\hline Rarely & 19 & 20.66 \\
\hline \multicolumn{3}{|c|}{ Reasons for going to summer camp ( $N=92)$} \\
\hline Spending summer without parents & 35 & 38.04 \\
\hline Meeting new people & 40 & 43.48 \\
\hline Being forced to go by parents & 17 & 18.48 \\
\hline \multicolumn{3}{|c|}{ Persons who choose the camp ( $N=92)$} \\
\hline Child & 23 & 25.00 \\
\hline Parents & 21 & 22.83 \\
\hline Child with parents & 48 & 52.17 \\
\hline \multicolumn{3}{|c|}{ Most important factors in camp choice $(\mathrm{N}=92)$} \\
\hline Programme meeting child's interests & 41 & 44.57 \\
\hline Attractive programme & 24 & 26.09 \\
\hline Innovative programme & 18 & 19.57 \\
\hline Location & 3 & 3.26 \\
\hline Standard of camp facilities & 2 & 2.17 \\
\hline Price & 4 & 4.35 \\
\hline \multicolumn{3}{|c|}{ Most popular types of camps ( $\mathrm{N}=92$ ) } \\
\hline Language & 9 & 9.78 \\
\hline Art & 16 & 17.39 \\
\hline Sports & 38 & 41.30 \\
\hline Military/survival & 9 & 9.78 \\
\hline Other & 20 & 21.74 \\
\hline \multicolumn{3}{|c|}{ Willingness to revisit a camp ( $\mathrm{N}=92)$} \\
\hline Yes & 69 & 75.00 \\
\hline No & 23 & 25.00 \\
\hline \multicolumn{3}{|c|}{ Reason for wanting to revisit a camp $(\mathrm{N}=69)^{5}$} \\
\hline Attractions & 20 & 28.99 \\
\hline Friendly educator & 23 & 33.33 \\
\hline Friendly instructors and animators & 22 & 31.88 \\
\hline Friends going there & 4 & 5.80 \\
\hline
\end{tabular}

Notes: ${ }^{4} \mathrm{~N}=92$ because only the respondents who attended summer camps answered questions related to this and subsequent aspects; ${ }^{5} \mathrm{~N}=69$ because only the respondents who went to the same camp more than once answered the question related to this aspect; * - the percentage of responses does not add up to 100 because the participants could select more than one answer.

opt for survival camps than girls $(\mathrm{p}=0.006)$, whereas girls were significantly more likely to participate in "other camp types" $(p=0.0360)$. Three-quarters of the respondents would eagerly return to a previously visited summer camp. For those partici- pants, a positive camp experience was determined mainly by the educators, animators, and instructors, followed by an attractive programme and the presence of friends.

The respondents were asked to evaluate different aspects of their stay in camp on a scale of 1 (least important) to 5 (most important).

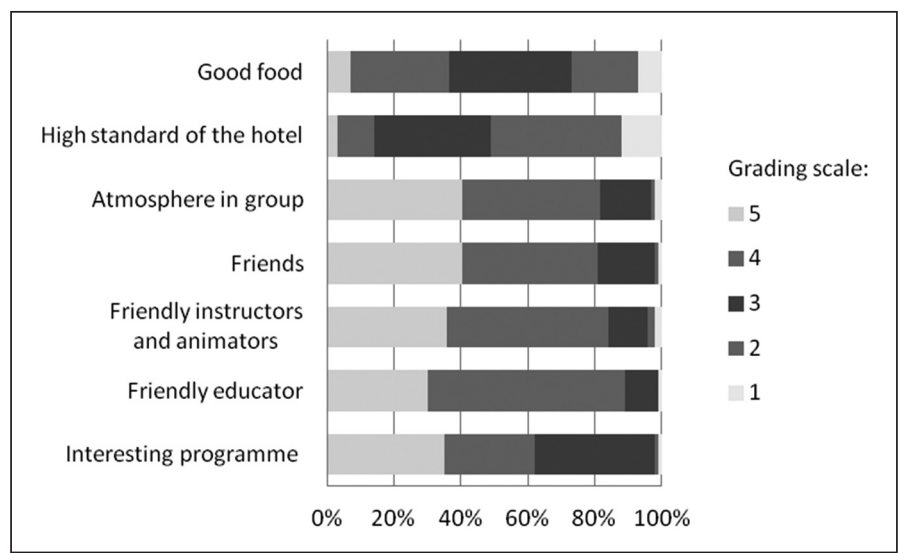

Figure 1. Factors that were most and least important for camp participants $(\mathrm{N}=92)$

The following factors were listed as most important: atmosphere in the group, presence of friends, friendly instructors and animators, friendly educators, and an interesting programme. A friendly educator was regarded as very important (5 points) by $30 \%$ of children and as important (4 points) by $59 \%$ of the respondents. Friendly instructors and animators were equally significant for the camp's success, and they received 5 points from $33 \%$ and 4 points from $44 \%$ of the subjects. Good food and the standard of camp facilities were regarded as the least important factors.

\section{Discussion}

The respondents who participated in the current study were first asked about the type of tourist events they had participated in. Most children had attended summer camps (91\%), and somewhat fewer had gone on school trips (83\%). In a study investigating the tourism activity of adolescents aged $10-18$ years, Żelazna and Górska-Warsewicz [11] reported that 86.7\% respondents had gone on school trips, and $54.3 \%$ had participated in summer camps not organised by schools. In a study by Omelan et al. [12], $97 \%$ of the students had gone on school trips, and $80.26 \%$ had attended summer camps. The popularity of summer camps and organised events for children and adolescents is on the rise. Parents and guardians recognise the health benefits of summer recreation, and they are more eager to pay for longer camp stays than short school excursions, which are relatively expensive. Summer camps are often co-financed by the parents' employers, whereas school excursions are subsidised only for students from the lowest-income families. Summer camps also provide parents with a longer break from parental duties. The results of a statistical analysis revealed a correlation between participation in school trips and the place of residence. Students from small towns were significantly less likely to take part in school excursions than children residing in medium-sized cities $(\mathrm{p}=$ 0.0422). The mother's education was also an important determinant of participation in school trips, and students whose mothers had university education were more likely to go on 
school/class trips than children whose mothers had vocational $(\mathrm{p}=0.0096)$ and secondary school $(\mathrm{p}=0.0072)$ education. The influence of education on tourism activity has been described in the literature $[13,14,15,16]$. In the present study, the mothers' higher levels of educational attainment (but not the education of other family members) significantly influenced children's participation in school trips, which likely indicates that better educated mothers were more aware of the benefits associated with such events.

Somewhat more than half of the population studied went on summer holidays with their parents, and $11 \%$ participated in family weekend outings. These results are highly encouraging because family outings build ties and integrate family members [17]. Green schools were the only tourist event for $2 \%$ of the subjects studied. According to a CBOS survey [9], children from 34\% Polish households did not leave home for a minimum weekly break during the summer holidays in 2016. This is the lowest percentage noted in recent years, but the number of children and adolescents who do not participate in organised summer events is still high in Poland.

According to a report of the Supreme Audit Office (NIK) [18], around 1,080,000 of Polish children and adolescents (23\% of all students) participated in summer and winter camps. These types of recreational activities are also popular in other countries. In the USA, around 12 million students attend summer camps, and nearly $7.5 \%$ of Canadian families send their children to camp programmes [1]. In this study, $92 \%$ of the respondents participated in summer camps, of which more than half went to camp every year. Statistical analysis revealed that the children of mothers with higher education were significantly more likely to attend summer camps than the children of mothers with vocational education $(p=0.0265)$, which confirms that education significantly influences tourist activity.

For most respondents, the main reason for going to camp was to make new friends. The desire to build interpersonal relations [19, 20] is characteristic of young people [11, 17, 21]. Therefore, it is not surprising that the subjects polled were most eager to go to summer camp to make friends outside of school. The remaining reasons were not consistent with the factors reported in the literature. Nearly $40 \%$ of the respondents went to camp because they enjoyed going on holiday without their parents; this is related to the fact that the study was conducted on students aged 11 to 17 for whom camps are probably the only summer getaway that does not involve parents or adult family members. Nearly $20 \%$ of the respondents claimed that they were forced to go to camp by their parents. The authors of this study have worked as summer camp consultants in travel agencies and as camp educators, and their experiences indicate that some parents do force their children to go to camp. Voluntary participation is a characteristic feature of tourism [22], but it may not always apply to children. In this particular case, there could be various reasons for the respondents' claim, but the parents' bad will can probably be ruled out. The fact that some parents make their children go to camp could be attributed to deep economic and, consequently, social and cultural changes in Poland. For some parents, camp is the only available day care option in certain periods of the summer. Children are increasingly likely to spend their free time at home and communicate with their peers through social media rather than in person. For this reason, some students do not feel the need to leave home and make new friends in camp where they could have limited access or no access to their telephones and the Internet [23]. Parents who "force" their children to go to camp probably think that they are doing it in the child's best interest. According to
$22.83 \%$ of the respondents, parents who make that decision also have the power to select the venue. However, the majority of the subjects polled chose the camp together with their parents, whereas 20\% did so independently. According to Thorton, Shaw, and Williams [24], children's influence on their tourism activity and the family's travel plans remains insufficiently investigated and therefore continues to be underestimated. Meanwhile, children have considerable say on how they spend their free time outside home by voicing their needs and negotiating with their parents (the authors analysed children's influence on families' holiday plans; however, their findings could be extrapolated to summer camps). In this study, summer camp choices were discussed during the interviews with travel agents who specialise in adolescents' recreation. In their opinion, tour organisers have a dual approach to their clients. Some programmes cater specifically to the needs of the youngest customers based on the assumption that parents merely sponsor the event, but it is the children who choose the destination. Other operators assume that children select summer camps together with their parents. The respondents were strongly in favour of the latter solution, and they argued that children and parents who browse travel packages together are more likely to make decisions that satisfy both parties. In families where the choice is made solely by the parents, children are less likely to be satisfied with the outcome. The results presented seem to confirm the above observation.

Tourist agencies need reliable information about factors which play a role in the choice of summer camp. In this study, less than $10 \%$ of the students surveyed claimed that the standard of camp facilities, the location, and the price were important considerations, which is not surprising because these factors are of far greater interest to adults than children. Most of the respondents placed the greatest emphasis on the camp programme. The majority were guided by their personal interests, which indicates that the respondents were characterised by considerable maturity or were highly involved in their hobbies. The subjects were also more keen on programmes offering a variety of options and new attractions. In contrast, the importance of camp attractions was emphasised by $17 \%$ and recreation by $52 \%$ of the respondents polled by Włastowski and Górska-Warsewicz [6]. The variety and quality of camp attractions were important considerations for the parents surveyed in this study; however, they placed the greatest emphasis on safety. Safety is a priority for the parents, especially when their children are not under their direct supervision. Camp accidents are widely reported in the media, which probably fuels the parents' anxiety. According to the Polish Ministry of National Education, 112 accidents, including 11 fatalities, were reported in summer camps in 2011-2014 [18]. In view of the above, the parents' qualms about safety seem to be fully justified. According to the tourist agents surveyed, in addition to the standard of camp facilities parents also pay considerable attention to the prices. In the agents' opinion, parents are increasingly likely to recognise the benefits of summer camps, but the price of the package plays an important role, since the higher the expectations are, the higher the cost is.

The students surveyed were most eager to participate in sports camps, followed by the "other camp types" category, mostly sailing camps and camps involving numerous physical activities. Summer camps play an important role in raising awareness about the importance of a healthy and active lifestyle; therefore, the growing popularity of sports and physical activity is a highly positive trend. Nonetheless, the role of active tourism and adventure tourism should not be reduced to a single summer event, and these activities should be promoted throughout the year. Attempts should be made to encourage interest in 
physical fitness and an active lifestyle, which greatly contribute to public health. Similar observations were made by American researchers [25] who noted that most summer camp goers meet the daily physical activity requirements appropriate for their age. They concluded that summer camps should be accessible to all children as part of public health care programmes. We believe a similar approach should be implemented in Poland.

Nearly $20 \%$ of the respondents had participated in art camps, and the remaining respondents had taken part in language and survival camps. The popularity of various camp types differed significantly between the sexes. Boys were significantly more likely to opt for survival camps than girls $(p=0.006)$, whereas girls were significantly more likely to participate in "other camp types" ( $p=0.0360)$. Travel agencies offer camps that are tailored to what they perceive to be the specific needs and interests of girls and boys. In general, most camps are open to both sexes, but targeted programmes are more likely to attract a higher number of either male or female participants.

According to one of the travel agents surveyed, summer camps offering a variety of sports activities and field trips enjoy the greatest popularity. Theme camps are the latest trend. Art camps during which children paint, draw, make jewellery, and cook are also popular. Similar observations were made by the second tour operator who admitted that summer camps packed with exciting activities were among the best-selling products. Camps without targeted activities or educational programmes are also popular if they organise dances, concerts, and outdoor events.

The types of summer camps sold by tourist agencies have evolved over the years. Many programmes that were popular in the past are no longer on offer. Some programmes were popular for only one season. Each year, tour operators search for new ideas that correspond to the latest trends on the adolescents' market. They conduct surveys with students and teachers, and they seek inspiration on social media.

The willingness to revisit a given venue was a measure of the respondents' general satisfaction with their stay in a summer camp. The majority of the polled adolescents were satisfied with their stay, and three-quarters were eager to return to a previously visited summer camp. For those participants, a positive camp experience was determined mainly by the educators, the atmosphere created by the animators and instructors, and an attractive programme. The selection of adequate camp personnel is a very important determinant of success, which has been confirmed by the travel agents surveyed. Camp organisers employ educators with extensive experience in summer recreation as well as young people, including university students majoring in education, physical education, tourism, and recreation, who acquire valuable professional experience during summer camps.

According to a study carried out by the Education Board of the Świętorzyskie Region [26], the number of young personnel members in summer camps has decreased over the years. In $2000,45.7 \%$ of camp staff were university or high school students, and $33.3 \%$ of the educators participated in summer camps for the first time. The organisers realised that suitably qualified personnel was essential for improving the quality of the programmes offered. However, the majority $(71.4 \%)$ of the educators did not have any qualifications for supervising sports or recreational activities, and $64.3 \%$ did not see the need to improve their qualifications. By 2009, high school seniors and graduates were no longer employed by camp organisers, and most educators were teachers from various fields of specialisation. University graduates with a degree in physical education who were well prepared to teach sports to children accounted for a growing proportion of camp educators. The significance of suitably qualified and friendly personnel during summer camps was also emphasised by Majewska and Dłużewska [27].

One of the tour operators surveyed relied on a questionnaire to monitor the satisfaction levels of camp participants. The data collected revealed that students focused mainly on camp personnel when mentioning what they were satisfied with. When asked to evaluate the camp programme, the respondents were more likely to give praise to instructors and animators than the content of the programme itself. The tour operator, who had extensive experience in organising summer camps, remarked that a simple field game coordinated by a charismatic instructor could be a much greater attraction than a ropes course in an adventure park. Camp participants' satisfaction was also largely determined by the educators. Younger children enjoyed their time in camp when they had caring supervisors, whereas adolescents appreciated educators who were involved in camp life.

According to the second tour operator, who elicited feedback information from camp participants and their parents through dedicated websites, social media, and by telephone and email, children and parents are interested in getting their money's worth. They scrupulously check whether all attractions listed in the catalogue have been included in the programme. Camp programmes are generally praised by the participants, who also frequently give praise to the educators and instructors.

The results of this study indicate that the factors that are most important for the parents are of negligible significance for camp goers. Most parents focus on the standard and cleanliness of camp facilities, the quality of the food and, above all, safety. In their opinion, friendly staff, in particular educators who directly supervise the children, are very important during summer camps. Parents are put at ease when their children establish good relations with camp educators, are happy with their stay, and praise the educators and the atmosphere in camp. Parents also give additional marks to camps employing professional nurses.

\section{Conclusions}

An attractive programme is one of the most important factors that determine the children's and parents' choice of a summer camp. However, children who establish good relations with camp personnel are most likely to enjoy their stay and have happy memories of the summer. Interestingly, neither the parents nor the children pay attention to the qualifications of camp educators and instructors. However, tour operators are aware that the success of a summer camp is determined largely by qualified personnel. The results of this study also indicate that the organisation of a summer camp requires a great deal of effort and involvement to guarantee the satisfaction of both the children and their parents. Children and parents are guided by completely different criteria; therefore, the product offered has to be skilfully designed to satisfy both parties.

\section{Literature}

1. Case E.K. (2012). Specialized summer camp for children and adolescents with learning disabilities: A naturalistic context for enhancing social competence, friendship, and self-concept. $\mathrm{PhD}$ thesis, University of Toronto. Retrieved February 05, 2018, from http://ccamping.org.

2. Nawara H., Cooper A. (2007). Summer camps: Healthy happy - safe. Wrocław: Wydawnictwo AWF. [in Polish] 
3. McCarthy A. (2015). Summer camp for children and adolescents with chronic conditions. Pediatric Nursing 41(5), 245-250.

4. Gula E., Sokołowski J. (2004). Summer camps. Wychowawca 7-8,18-19. [in Polish]

5. Demakova I.D., Valeeva R.A., Shipova A.V. (2016). Socialization of adolescents: Cultural practices in children's summer camp. International Journal of Environmental E Science Education 11(7), 1631-1640.

6. Włastowski Ł., Górska-Warsewicz H. (2016). Designing a holiday marketing product for children and youth. Przedsiębiorczość i Zarządzanie 17(9), part 3, 119-128. [in Polish]

7. Zarzycka M. (2011). Report on youth tourism. Wiadomości Turystyczne, Retrieved on January 17, 2018, from http:// www.wiadomosciturystyczne.pl. [in Polish]

8. German M. (2017). School and youth tourism with good prospects. Wiadomości Turystyczne, March 2017, Special Issue. [in Polish]

9. Public Opinion Research Centre (CBOS). (2016). Leisure travel and summer jobs among students. Report from research no. 135/2016. Retrieved on January 20, 2018, from https://www.cbos.pl/PL/publikacje/raporty.php. [in Polish]

10. Zarzycka M. (2011). Report on youth tourism continued. Wiadomości Turystyczne 04.04.2011. Retrieved January 17, 2018, from http://www.wiadomosciturystyczne.pl. [in Polish]

11. Żelazna K., Górska-Warsewicz H. (2013). Tourism behaviour of youth. Problemy Turystyki i Rekreacji 2, 36-51. [in Polish]

12. Omelan A., Huk-Wieliczuk E., Podstawski R. (2015). Education related to tourism received by Polish tourism and recreation students in childhood and adolescence and its impact on their tourism activity. Polish Journal of Sport and Tourism 20, 95-104.

13. Gaworecki W. (2003). Tourism. Fourth edition revised. Warszawa: Polskie Wydawnictwo Ekonomiczne S.A. [in Polish]

14. Parzych K. (2010). Determinants of tourism activity of school youth based on the example of high school youth from Słupsk and Częstochowa. Turyzm 20(1), 37-44. [in Polish]
15. Statistics Poland (GUS). (2014). Tourism and leisure in households in 2013. Warszawa: GUS. [in Polish].

16. Statistics Poland (GUS). (2017). Tourism in 2016. Warszawa: GUS. [in Polish].

17. Tomczykowska P. (2013). Socioeconomic determinants of youth tourism. Zeszyty Naukowe no. 1l, Seria geograficznoturystyczna no. 6, SWPR, 21-52. [in Polish]

18. Supreme Audit Office (NIK). (2015). Safety of children's and youth's leisure. Information about the results of the inspection. Warszawa: NIK, Departament Nauki, Oświaty i Dziedzictwa Narodowego. [in Polish]

19. Crompton J.L. (1979). Motivations for pleasure vacation. Annals of Tourism Research 6(4), 408-424.

20. Kozioł L. (2012). Typology of travel motivation factors. Zeszyty Naukowe Małopolskiej Wyższej Szkoły Ekonomicznej w Tarnowie 20(1), 88-98. [in Polish]

21. Borek Z., Eider J., Mynarski W., Rozpara M., Puciato D. (2011). Tourism activity of youth aged between 15 and 17 years. Ekonomiczne Problemy Usług 78, 285-299. [in Polish]

22. Przecławski K. (1997). Man and tourism. Outline of tourism sociology. Kraków: Impuls. [in Polish]

23. Bury M. (2017). Summer camps only without mobile phones? Retrieved on February 7, 2018, from https://parenting. $\mathrm{pl} /$ na-kolonie-letnie-tylko-bez-telefonu-komorkowego. [in Polish]

24. Thorton P.R., Shaw G., Williams A.M. (1997). Tourist group holiday decision-making and behaviour: The influence of children. Tourism Management 18(5), 287-297.

25. Brazendale K., Beets M.W., Weaver R.G., Chandler J.L., Randel A.B., Turner-McGrievy G.M. et al. (2017). Children's moderate to vigorous physical activity attending summer day camps. American Journal of Preventive Medicine 53(1), 78-84.

26. Mazur A. (2010). Camp offerings and the needs and expectations of children and youth. Wychowanie Fizyczne i Zdrowotne 10, 30-34. [in Polish]

27. Dłużewska A., Majewska D. (2015). Summer camps as an appropriate form of spending leisure time for children? Tleń and Jarosławiec camps: Case study analysis. Geography and Tourism 3(2), 71-80. [in Polish]

Submitted: April 20, 2018

Accepted: September 26, 2018 